\title{
Genetic diversity of Salminus brasiliensis (Characiformes: Characidae) collected in the passage ladder of the Canoas I hydropower plant in the Paranapanema River, Brazil
}

\section{Diversidade genética de Salminus brasiliensis (Characiformes: Characidae) coletados na escada de transposição da Hidrelétrica de Canoas I, rio Paranapanema, Brasil}

\author{
Patricia Cristina Gomes ${ }^{1}$; Nelson Mauricio Lopera-Barrero ${ }^{2 *}$; \\ Lauro Vargas ${ }^{3}$; Danilo Pedro Streit Junior ${ }^{4}$; Jayme Aparecido Povh ${ }^{5}$; \\ Rodolfo Nardez Sirol ${ }^{6}$; Ricardo Pereira Ribeiro ${ }^{3}$
}

\begin{abstract}
The aim of this study was to evaluate the genetic diversity of Salminus brasiliensis collected three times in the passage ladder of the hydropower plant Canoas I, in the Paranapanema River (Brazil). Fish samples were collected on 14 (CI14), 18 (CI18) and 25 (CI25) February 2008. Eight primers using RAPD technique were evaluated. Seventy-nine in 105 fragments amplified using these primers were polymorphic fragments $(75.2 \%), 32$ had frequencies with significant differences $(\mathrm{P}<0.05), 10$ had low frequencies, 25 were excluded, and four were fixed fragments. One exclusive fragment was found in the CI14 sample. High values for polymorphic fragments and genetic diversity index of Shannon were observed for the CI14 and CI18. Low ancestry levels among the groups were indicated by the $\mathrm{F}_{\mathrm{ST}}$ values that indicated high genetic differentiation. In all the three groups, the estimates of the number of migrants by generation $(\mathrm{Nm})$ indicated low levels of gene flow. Most of the genetic variation was found within the groups through the AMOVA analysis, which was confirmed by the results of the identity and genetic distance. The results indicate high variability within the groups and genetic differentiation among them.
\end{abstract}

Key words: Dourado, fish transposition, genetic variability, RAPD, restocking programs

\section{Resumo}

O objetivo do presente estudo foi avaliar a diversidade genética de Salminus brasiliensis coletados em três períodos diferentes na escada de transposição da hidrelétrica de Canoas I no rio Paranapanema

1 Pesquisadora Dra em Zootecnia, Instituto Agronômico do Paraná, IAPAR, Rod. Celso Garcia Cid, km 375 CEP 86047-902, Londrina, PR. E-mail: patriciacgomes@iapar.br

2 Prof. Dr. em Zootecnia, Dept ${ }^{\circ}$ de Zootecnia, Universidade Estadual de Londrina, UEL, Rod. Celso Garcia Cid, PR 445 km 380 , Campus Universitário, CEP 86.057-970, Londrina, PR. E-mail: nmlopera@uel.br

3 Profs. Drs. em Zootecnia, Dept ${ }^{\circ}$ de Zootecnia, Universidade Estadual de Maringá, UEM, Av. Colombo, nº 5.790, Jd. Universitário, CEP 87020-900, Maringá, PR. E-mail: lvargas@uem.br; rpribeiro@uem.br

4 Prof. Dr. em Zootecnia, Dept ${ }^{\circ}$ de Zootecnia, Universidade Federal do Rio Grande do Sul, UFRGS, Av. Bento Gonçalves, 7712, CEP 915400-000, Porto Alegre, RS. E-mail: danilo.streit@ufrgs.br.

5 Prof. Dr. em Zootecnia, Universidade Federal do Mato Grosso do Sul, Faculdade de Medicina Veterinária e Zootecnia, Av. Senador Filinto Muller, nº 2443, CEP 79070-460, Campo Grande, MS. E-mail: jayme.peixegen@gmail.com

6 Pesquisador Dr. em Zootecnia, Companhia Paulista de Força e Luz, CPFL, Rod. Campinas-Mogi Mirim, Km 2,5, CEP 13088900 Campinas, SP. E-mail: rnsirol@cpfl.com.br

* Author for correspondence 
(Brasil). Os peixes foram coletados no dia 14 (CI14), 18 (CI18) e 25 (CI25) do mês de fevereiro de 2008. Foram avaliados oito iniciadores com a técnica de RAPD. Dos 105 fragmentos amplificados pelos iniciadores, 79 foram polimórficos $(75,2 \%), 32$ tiveram diferenças significativas $(p<0,05)$ na frequência, 10 fragmentos tiveram baixa frequência, 25 fragmentos foram excluídos e quatro fragmentos foram fixados. Um fragmento exclusivo foi encontrado em CI14. Observaram-se altos valores de porcentagem de fragmentos polimórficos e índice de diversidade genética de Shannon em CI14 e CI18. O valor de $F_{\text {st }}$ mostrou que existe uma baixa ancestralidade entre os agrupamentos sugerindo uma alta diferenciação genética entre os grupos amostrados. $\mathrm{O}$ valor de número de migrantes por geração $(\mathrm{Nm})$ calculado foi baixo nos três grupos, sendo considerado como baixa presença de fluxo gênico. De acordo com a AMOVA, a maior parte da variação genética está dentro de cada grupo e não entre os grupos, sendo confirmado com as estimativas da identidade e da distância genética. Os resultados deste estudo indicam que existe uma alta variabilidade genética e diferenciação genética entre os grupos amostrados.

Palavras-chave: Dourado, programas de repovoamento, RAPD, transposição de peixes, variabilidade genética

\section{Introduction}

The Paranapanema River with a basin of $100,800 \mathrm{~km}^{2}$ is part of the border line between the states of Paraná and São Paulo, and one of the most important left-bank tributary into the Parana River (BRITTO et al., 2003).

Recently, there has been in the Paranapanema River a decline in the population of various wild fishes like the dourado (Salminus brasiliensis). The main factors responsible for this decline have been the intense deforestation in the river banks, excessive fishing of juveniles, drainage of nearby lagoons, the regulatory hydrological regimen, the water pollution, and the introduction of exotic fishes (AGOSTINHO; THOMAZ; GOMES, 2005; POVH et al., 2008, LOPERA-BARRERO, 2009, VIANA et al., 2010). Moreover, the Paranapanema River has 10 hydropower plants as the Canoas I that changed the original river flow into a sequence of water reservoirs (LEUZZI et al., 2004). These dams have broken the migratory path, interfered with the life cycle of numerous aquatic organisms, and produced major changes in ecosystems (AGOSTINHO; GOMES; SUZUKI, 2003).

The hydropower plant of Canoas I was built in 1998 (LOPES et al., 2007) and the passage ladder was built within the above scenario to permit an alternative route to the natural flow of the migratory species. However, these ladders have been criticized for their behavior unidirectional (BRITTO; SIROL, 2006), selectivity of the fish (AGOSTINHO et al., 2007a), and their inefficiency in allowing downstream return by adults, eggs, and larvae (AGOSTINHO et al., 2007b). Therefore, even with a fish ladders, a dam can restrict the gene flow between fish populations located upand downstream of the barrier, likely leading to interpopulational structuring (ESGUÍCERO; ARCIFA, 2010).

Another decision that has made possible to preserve the fish fauna is the regional development of restocking programs (POVH et al., 2010). Although they have been releasing fish for about three decades in Brazil, risks associated with its failure of stimulating the population size (ARAKI; SCHMID, 2010), increase the ecological competition between wild and captive-bred individuals (ELDRIDGE; NAISH, 2007), impact in other species in the ecosystem (ARAKI; COOPER; BLOVIN, 2009) and reduce the genetic diversity and population viability of wild stocks (AGOSTINHO; THOMAZ; GOMES, 2005; KITADA et al., 2009) are questionable.

In this context, the genetic variation of wild fish populations must be monitored and the correct election of the individuals to be used in the formation of broodstock is a crucial step (BORREL et al., 2007) to increase the preservation of wild fishing resources in restocking programs. Thus, the 
RAPD (Random Amplified Polymorphic DNA) has been applied to estimate the genetic diversity of various wild fish populations (PAMPONET et al., 2008; LOPERA-BARRERO et al., 2010a), the stock levels in captivity (POVH et al., 2009) and the fish lines (LUPCHINSKI JUNIOR et al., 2008).

The objective of the present study was to evaluate, using the RAPD technique, the genetic diversity of Salminus brasiliensis collected in the passage ladder of the hydropower plant Canoas I in the Paranapanema River, in Brazil.

\section{Material and Methods}

\section{Sampling characteristics}

Fish samples collected in the passage ladder of the hydropower plant Canoas I ( $22^{\circ} 56^{\prime} \mathrm{SL}, 50^{\circ} 31^{\prime}$ WL) on 14 February 2008 were named as CI14, on 18 February they were named as CI18 and on 25 February they were named as CI25. The sampling number collected every time was 81,54 and seven fish, respectively. Thereafter, a total of 142 samples from their caudal fins were collected. Every caudal sample weighed between 300 and $400 \mathrm{mg}$. These samples were stored in micro tubes with ethyl alcohol before the DNA analysis. The specimens were maintained at the Estação de Hidrologia e Aquicultura at the Duke Energy International (Salto Grande - SP) to produce offspring to supply the restocking program in the Paranapanema River.

\section{DNA extraction and quantification}

Forty caudal fin samples taken from fish collected in the CI14 and CI18 periods, and seven collected in the CI25 were analyzed. The analysis was carried out in the Laboratory of Molecular Biology in the Núcleo de Pesquisa Peixegen/DZO at the Universidade Estadual de Maringá (UEM-PR). The DNA protocol followed the recommendation of Lopera-Barrero et al. (2008). In the micro tubes, was added $550 \mu \mathrm{L}$ of lyses buffer ( $50 \mathrm{mM}$ Tris-HCl,
$50 \mathrm{mM}$ EDTA, $100 \mathrm{mM} \mathrm{NaCl}$ ), SDS $1 \%$ and $7 \mu \mathrm{L}$ of the proteinase $\mathrm{K}(200 \mu \mathrm{g} / \mathrm{mL})$. These micro tubes were maintained in water bath at $50^{\circ} \mathrm{C}$ for 12 hours. The DNA was precipitated with $600 \mu \mathrm{L}$ of $\mathrm{NaCl}(5$ $\mathrm{M})$ and centrifuged at $12.000 \mathrm{rpm}$ for 10 minutes. The supernatant with the DNA was transferred to other micro tube $(600 \mu \mathrm{L})$, precipitated with 700 $\mu \mathrm{L}$ of ethyl alcohol and maintained at $-20^{\circ} \mathrm{C}$ for 1 hour. The DNA was centrifuged and rinsed with $700 \mu \mathrm{L}$ of $70 \%$ ethyl alcohol. The pellets under environmental temperature for about 20 minutes were dried. Thereafter, they were re-suspended in $80 \mathrm{~mL}$ of the buffer TE $(10 \mathrm{mM}$ Tris $\mathrm{pH} 8.0$ and 1 mM EDTA), treated with $7 \mu \mathrm{L}$ of RNAse $(30 \mathrm{mg} /$ $\mathrm{mL}$ ) in water bath at $37^{\circ} \mathrm{C}$ for 1 hour, and stored at $-20^{\circ} \mathrm{C}$ in the horizontal freezer.

The DNA was quantified in the Shimadzu spectrophotometer with absorbance at $260 \mathrm{~nm}$. The samples were diluted to the concentration of $10 \mathrm{ng} /$ $\mu \mathrm{L}$. The DNA quality was checked using agarose gel electrophoresis buffered with TBE 1X (500 mM Tris-HC1, $60 \mathrm{mM}$ boric acid and $83 \mathrm{mM}$ EDTA) at 70 volts for 1 hour.

\section{Amplification and DNA electrophoresis}

The genomic DNA was amplified in the reaction volume of $15 \mathrm{ml}$ using the buffer Tris- $\mathrm{KCl} 1 \mathrm{X}$ (Tris- $\mathrm{HCl} 20 \mathrm{mM} \mathrm{pH} 8.4$ and $\mathrm{KCl} 50 \mathrm{mM}$ ), 2.5 $\mathrm{mM} \mathrm{MgCl}_{2}, 0.46 \mathrm{mM}$ primer (oligonucleotides), $0.2 \mathrm{mM}$ from every dNTPs, one unit of Taq DNA Polymerase and 10 ng of DNA. The RAPD reactions were amplified in the "Eppendorf Mastercycler" Gradient" thermocycler, programmed to 40 cycles, initial step of denaturation at $92^{\circ} \mathrm{C}$ for 4 minutes and a final step of extension at $72^{\circ} \mathrm{C}$ for 5 minutes. Every cycle consisted of 40 seconds at $92^{\circ} \mathrm{C}, 1.5$ minutes at $40^{\circ} \mathrm{C}$ and 2 minutes at $72^{\circ} \mathrm{C}$.

60 primers from the Operon Kit (Operon Technologies Inc. in Alameda, California, USA) were evaluated. However, only eight selected primers with a good standard to the amplification were used. The product from the amplification 
was separated in agarose gel at $1.4 \% .15 \mathrm{ml}$ of the amplified product and $2 \mathrm{ml}$ of the sampling buffer $(40 \%$ sucrose and $0.25 \%$ bromophenol blue) were used in horizontal electrophoresis. The electrophoresis was carried out at 70 volts for 4 hours $(3 \mathrm{~V} / \mathrm{cm})$ using the buffer TBE $1 \mathrm{X}(500 \mathrm{mM}$ Tris-HCl, $60 \mathrm{mM}$ boric acid and $83 \mathrm{mM}$ EDTA). Every reaction had a negative control $(\mathrm{N})$ where all the previous components but DNA were added to the solution. A bath with ethidium bromide at 0.5 $\mathrm{mg} / \mathrm{ml}$ for 30 minutes was used to reveal the gel. Thereafter, the gels were photographed using the EDAS system (Kodak 1D Image Analysis 3.5).

\section{Data analysis}

Fragments of identical molecular size were used to form the similarity matrix based on the Jaccard coefficients coded as 1 for the presence or 0 for the absence of these fragments. The percentage of polymorphic fragments and the index of genetic diversity of Shannon were obtained from the POPGENE software version 1.31 (YEH; BOYLE; XIYAN, 1999). The software TFPGA 1.3 (MILLER, 1997) was used to estimate the identity and genetic distance (NEI, 1978) among the groups. The frequency of fragments was estimate by the exact test of Raymond and Rousset (1995). The software ARLEQUIN 3.0 (EXCOFFIER; LAVAL; SCHNEIDER, 2005) was used to determine the genetic differentiation using the estimates of the $F_{\text {st }}$ (WEIR; COCKERHAM, 1984), the number of migrants per generation $(\mathrm{Nm})$ and the molecular analysis of variance - AMOVA (EXCOFFIER; SMOUSE; QUATTRO, 1992). The molecular variance between the groups was evaluated after combining all of them in the following groups: CI14 x CI18, CI14 x CI25 and CI18 x CI25. The significance of these tests was determined by the random permutation method using from 1,000 to 10,000 permutations. The significance of the $F_{\text {st }}$ was tested by the $\mathrm{X}^{2}\left[\mathrm{c}^{2}=2 \mathrm{n} F_{\mathrm{st}}(\mathrm{k}-1) ; \mathrm{GL}=(\mathrm{k}-1)(\mathrm{s}-1)\right]$ after Workman and Niswander (1970) in which $\boldsymbol{n}$ is the number of individuals in two groups, $\boldsymbol{k}$ is the number of alleles and $s$ is the number of groups. The magnitude of the genetic differentiation between these groups was based on the Wright (1978) definition as having little differentiation when $F_{\mathrm{st}}$ is ranging between 0 and 0.05 , moderate when $F_{\text {st }}$ is ranging between 0.051 and 0.15 , great when the $F_{\text {st }}$ is ranging between 0.151 and 0.25 and very great when the $F_{\text {st }}$ is above 0.25 .

\section{Results}

Seventy-nine amplified fragments were polymorphic $(75.2 \%)$ and 26 were monomorphic $(24.8 \%)$. The number of clear and reproducible fragments generated per primer ranged from eight (primer OPX12) to 19 (primer OPX09). The biggest fragment (2600bp) was obtained from the primer OPX09 and the smaller (200bp) from the primers OPX09 and OPA02 (Table 1). Third-two in 105 fragments had significant differences in their frequencies $(\mathrm{P}<0.05)$. The total of ten fragments with low frequency (lower than 0.100) were found in the three groups (CI14 =2; CI18 = 7; CI25 = 1). Twenty-five were excluded fragments - frequency of $0.000(\mathrm{CI} 18=5 ; \mathrm{CI} 25=20)$, and four were fixed fragments - frequency of $1.000(\mathrm{CI} 14=1 ; \mathrm{CI} 18=$ 3) (Table 2). 
Table 1. Nucleotide sequence in the primers, percentage of $\mathrm{G}+\mathrm{C}$ bases, number of fragments (NF), number of polymorphic fragments (NPF), and size of the amplified fragments from the groups of S. brasiliensis.

\begin{tabular}{cccccc}
\hline Primers & Sequence $\left(3^{\prime} \rightarrow 5^{\prime}\right)$ & $\%^{\prime}(\mathrm{G}+\mathrm{C})$ & NF & NPF & Size $(\mathrm{bp})$ \\
\hline OPX01 & CTG GGC ACG A & 70 & 11 & 07 & $550-2500$ \\
OPX06 & ACG CCA GAG G & 70 & 13 & 05 & $400-2072$ \\
OPX07 & GAG CGA GGC T & 70 & 12 & 10 & $600-2072$ \\
OPX09 & GGT CTG GTT G & 60 & 19 & 17 & $200-2600$ \\
OPX12 & TCG CCA GCC A & 70 & 08 & 04 & $700-2072$ \\
OPX13 & ACG GGA GCA A & 60 & 13 & 10 & $400-2072$ \\
OPA02 & TGC CGA GCT G & 70 & 17 & 17 & $200-2072$ \\
OPA16 & AGC CAG CGA A & 60 & 12 & 09 & $300-2500$ \\
\hline Total & - & - & 105 & 79 & $200-2600$ \\
\hline
\end{tabular}

Source: Elaboration of the authors.

Table 2. Characterization, size and frequency of fragments with significant values using the exact test $(\mathrm{P}<0.05)$ on the groups of $S$. brasiliensis. ${ }^{*} \mathrm{P}<0.05$.

\begin{tabular}{|c|c|c|c|c|c|}
\hline Primer & Size (bp) & CI14 & CI18 & CI25 & $\mathrm{p}$ \\
\hline \multirow{5}{*}{ OPX01 } & 2700 & $0,051^{*}$ & $0,097 *$ & 0,302 & 0,002 \\
\hline & 2600 & 0,157 & 0,494 & $0,000^{*}$ & 0,000 \\
\hline & 500 & 0,189 & $0,039 *$ & $0,000 *$ & 0,002 \\
\hline & 400 & 0,173 & $0,013^{*}$ & $0,000^{*}$ & 0,003 \\
\hline & 300 & 0,189 & $0,013^{*}$ & $0,000 *$ & 0,002 \\
\hline \multirow[t]{4}{*}{ OPX06 } & 2700 & 0,194 & $0,000^{*}$ & $0,000^{*}$ & 0,001 \\
\hline & 2700 & $0,051^{*}$ & 0,293 & $0,000^{*}$ & 0,001 \\
\hline & 2500 & 0,163 & 0,526 & $0,000^{*}$ & 0,001 \\
\hline & 2072 & 0,452 & $1,000^{*}$ & $0,000^{*}$ & 0,000 \\
\hline \multirow[t]{7}{*}{ OPX07 } & 1900 & 0,106 & 0,613 & 0,476 & 0,002 \\
\hline & 1700 & 0,367 & 0,726 & $0,000 *$ & 0,001 \\
\hline & 1000 & 0,367 & 0,842 & 0,842 & 0,001 \\
\hline & 800 & 0,225 & 0,646 & $0,000 *$ & 0,000 \\
\hline & 2200 & 0,553 & $1,000^{*}$ & $0,000 *$ & 0,002 \\
\hline & 2072 & 0,776 & 0,526 & $0,000^{*}$ & 0,004 \\
\hline & 2000 & 0,163 & 0,776 & 0,842 & 0,000 \\
\hline \multirow[t]{4}{*}{ OPX09 } & 1000 & 0,476 & 0,258 & $0,000^{*}$ & 0,003 \\
\hline & 800 & 0,311 & 0,106 & $0,000^{*}$ & 0,001 \\
\hline & 500 & 0,367 & 0,553 & 0,120 & 0,002 \\
\hline & 320 & 0,258 & $0,025^{*}$ & 0,000 * & 0,001 \\
\hline \multirow{3}{*}{ OPX12 } & 2100 & 0,225 & $0,000^{*}$ & 0,552 & 0,002 \\
\hline & 2072 & 0,225 & $0,000^{*}$ & 0,552 & 0,002 \\
\hline & 1900 & 0,452 & $1,000^{*}$ & $0,000^{*}$ & 0,001 \\
\hline \multirow{3}{*}{ OPX13 } & 1100 & 0,452 & $0,000^{*}$ & 0,842 & 0,002 \\
\hline & 700 & 0,163 & 0,225 & 0,500 & 0,002 \\
\hline & 500 & 0,293 & 0,367 & 0,613 & 0,001 \\
\hline \multirow{2}{*}{ OPA02 } & 480 & 0,209 & $0,051^{*}$ & $0,000 *$ & 0,001 \\
\hline & 380 & 0,194 & $0,013 *$ & $0,000 *$ & 0,001 \\
\hline \multirow{4}{*}{ OPA16 } & 2700 & 0,430 & 0,414 & $0,000 *$ & 0,000 \\
\hline & 2500 & 0,324 & 0,134 & $0,000^{*}$ & 0,000 \\
\hline & 1400 & $1,000^{*}$ & 0,258 & 0,367 & 0,000 \\
\hline & 1300 & 0,225 & $0,000 *$ & $0,014^{*}$ & 0,000 \\
\hline
\end{tabular}

Source: Elaboration of the authors. 
The percentage of polymorphic fragments (71.43 and $63.81 \%)$ and the index of Shannon (0.382 and 0.287) were higher in the CI14 and CI18 groups than in the CI25 (33.33\% and 0.174). These results indicate a higher genetic variability in the first two groups.

The $\mathrm{F}_{\text {st }}$ showed low ancestry between CI14 x CI18, CI14 x CI25 and CI18 x CI25. These results suggest a very high and a high genetic differentiation among the groups. Corroborating this hypothesis, the $\mathrm{Nm}$ was low in all the groups suggesting a low gene flow. The higher value of Nm between CI14 and CI18 was 0.372 individuals per generation (Table 3).

According to the analysis of molecular variance (AMOVA), most of the genetic variation occurs within every group of $S$. brasiliensis $(62.81,72.73$ and $80.17 \%)$ unlike between them $(37.19,27.27$ and $19.83 \%$ ). These results were confirmed by the estimates of the identity and the genetic distance (Table 4).

Table 3. $F_{\text {st }}$, $\mathrm{X}^{2}$ test for the $F_{\text {st }}$, genetic differentiation according to Wright (1978) and number of migrants (Nm) in the different groups of $S$. brasiliensis. $* \mathrm{P}<0.05$.

\begin{tabular}{cccccc}
\hline Groups & Number of fish & $F_{\text {sf }}$ & Wright & $X^{2}$ & Nm \\
\hline CI14 x CI18 & 80 & $0.372^{*}$ & Very high & 59.52 & 1.68 \\
CI14 x CI25 & 47 & $0.273^{*}$ & Very high & 25.66 & 2.46 \\
CI18 x CI25 & 47 & $0.198^{*}$ & High & 18.61 & 4.35 \\
\hline
\end{tabular}

Source: Elaboration of the authors.

Table 4. Molecular analyses of variance (AMOVA), genetic distance (D) and genetic identity (I) for the different groups of $S$. brasiliensis. B.G = between group; W.G = within group $* \mathrm{P}<0.05$.

\begin{tabular}{lcccccc}
\hline Groups & $\begin{array}{c}\text { Source of } \\
\text { variation }\end{array}$ & Sum of squares & $\begin{array}{c}\text { Variance } \\
\text { components }\end{array}$ & \% of variation & D & I \\
\hline \multirow{4}{*}{ C114 x CI18 } & B.G & 86.515 & 6.3596 & $37.19^{*}$ & 0.067 & 0.935 \\
& W.G & 483.357 & 10.741 & 62.81 & & \\
\cline { 2 - 7 } & Total & 569.872 & 17.100 & 100 & & 0.928 \\
CI14 x CI25 & B.G & 163.725 & 3.8372 & $27.27 *$ & 0.075 & \\
& W.G & 798.350 & 10.235 & 72.73 & & \\
\hline \multirow{2}{*}{ CI18 x CI25 } & Total & 962.075 & 14.072 & 100 & & 0.867 \\
& B.G & 35.506 & 2.2251 & $19.83^{*}$ & 0.143 & \\
\hline
\end{tabular}

Source: Elaboration of the authors.

\section{Discussion}

The RAPD analysis was appropriate to evaluate the genetic diversity within and between the groups of $S$. brasiliensis collected in the passage ladder of the UHE of Canoas I. The main problems towards the dominant performance of this technique (BENTER et al., 1995) were overcome through the amplification tests and standardization of samples carried out in conjunction with the negative controls in the different amplifications.

The percentage of polymorphic fragments and the Shannon index showed high genetic variability for the CI14 and CI18 groups unlike for the CI25. In fact, the results from the CI 25 could have been 
influenced by the low number of samples collected (seven fish). Therefore, there are high genetic variability within every group despite the low frequency of fragments and a significant number of excluded fragments (Table 2). These results for the wild populations are important since that the presence of heritable variations makes the fish skillful and able to reproduce and survive under selection pressure (LOWE; HARRIS; ASHTON, 2004; RAMOS, 2007). In contrast, Lopes et al. (2007) reported a lower percentage of polymorphic fragments (42.19\%) for S. brasiliensis also collected in Canoas I, but they stated that this level was still appropriate for these wild populations.

The high genetic variability observed in the present study demonstrate that despite the restocking program of the Estação de Hidrologia e Aquicultura of the Duke Energy International, the genetic diversity of this wild population is still displaying high values. These results may indicate a higher adaptation of this species to the environmental conditions in this ecosystem (LOPERA-BARRERO et al., 2010a). However, was unable to determine whether these sampled groups are formed from individuals from previous releases of offspring. Thus, a broad sampling from wild populations in conjunction with the analysis of the fish stocks used in these programs throughout reproductive period, as well as investments in the synthesis of specific microsatellite markers that yet does not exist would be more appropriate to prove that fish collected in the passage ladder came from these programs. Moreover, this approach will confirm that the restocking programs have been effective in the preservation of the wild fish populations. As these current samples of fish will form a new stock for attending the requirement of these programs, the next fish stock will have a broad genetic base to produce offspring without inducing unnecessary genetic risks to the wild populations.

Conversely, the decline in the genetic variability may induce problems of adaptability and survivorship of these offspring, and negative influences on the ecosystem (LOPERA-BARRERO et al., 2010b). In a worst scenario, species can be extinct (AGOSTINHO; THOMAZ; GOMES, 2005). Thus, all the fish released during restocking programs should represent the wild populations (LOPERA-BARRERO, 2009), and both must have their genetic analysis evaluated (RODRIGUEZRODRIGUEZ et al., 2010).

The presence of the exclusive fragment in CI14 indicates that the groups tend to differentiate. This tendency was verified by the $\mathrm{F}_{\text {st }}$ values $(\mathrm{P}<0.05)$ which characterized the differentiation as very high (CI14 x CI18 and CI14 x CI25) and high (CI18 x CI25). The number of migrants $(\mathrm{Nm})$ also corroborates this differentiation because of its low values that assume the absence of gene flow (Table 3).

Similarly, the AMOVA and the genetic distance showed that the highest fraction of the genetic variation is within all these three groups and not among them. The moderate distance between them are revealing genetic differentiation among the groups or different population structures (Table 4). The variation component within every group indicates that the sample size allowed us to find a large proportion of genetic variability in the wild population collected in the passage ladder of Canoas I. This approach is very important for the management and preservation programs (PAULA, 2006).

The results from the $F_{\mathrm{st}}$, AMOVA and genetic distance observed in this study are different from the report of Lopes et al. (2007) who found low genetic differentiation $\left(F_{\mathrm{st}}: 0.014\right.$; genetic distance: $0.006)$ among groups collected in the Canoas I (17 fish collected in March, 2003 and 24 fish collected from November to March, 2004/2005). They concluded that those groups were sampled from a single population. Studies with other migratory fish as Leporinus elongatus (RAMOS, 2007), Prochilodus lineatus (PAULA, 2006) and Piaractus mesopotamicus (LOPERA-BARRERO et al., 2010a) collected in the same passage ladder also showed a single population structure. 
The Salminus brasiliensis that reproduces during the rainy season has its reproductive migratory performance from October to March which is the hottest period of the year (MACHADO, 2003). Therefore, the sampling in three different times when the highest migratory populations may be between the middle and the end of the reproductive period could have induced this genetic structure that differs from previous reports in the same place. The Dourado is a long-distance migratory species (FEITOSA et al., 2004; FREITAS, 2010) that covers from 100 to $1440 \mathrm{~km}$ (BONETTO et al., 1971; SVERLIJ; ESPINACH ROS, 1986), and this performance permit this large migratory period within the reproductive stage.

Another factor that could have had influence on the genetic structure was the sampling place because Dias (2003), who evaluate the genetic diversity in eight locations in the middle Paranapanema between October 1993 and October 1995, stated that the complex of Canoas I had the highest relative frequencies of $S$. brasiliensis (0.5\%). Similarly, Britto and Sirol (2006), who evaluated four consecutive periods (2000/2001; 2001/2002; $2002 / 2003$; 2003/2004) in the passage ladder of Canoas I, reported increases in the percentage of Characiformes in all of them, and increases in other migratory populations comprised by medium- and big-size fish in 2001/2002 (58.73\%) and 2002/2003 (88.96\%). These responses corroborate the present study in which a large number of $S$. brasiliensis were collected in a short period (CI14: 81 fish; CI18: 54 fish). Small sample size (CI25: 7 fish) was collected a only at the end of the reproductive period.

The decreasing order of the sample size along these sampling periods (CI14 $=81$, CI18 $=54$ and CI25 = seven fish) was also reported for this same species by Lopes et al. (2007). Similarly, LoperaBarrero et al. (2010a) reported from the complex Canoas I and Canoas II a similar decline in the population of Piaractus mesopotamicus. These results were attributed to the dam effects and the presence of depleted downstream populations. Nonetheless the quantity of 135 fish collected in the first two periods of five days, the current results permitted us to state that the ladder has been an efficient passage for fish to go up the dams in the middle Paranapanema River. Otherwise, more research is still necessary to determine the efficacy of these ladders on the natural reproduction of migratory fish species as the $S$. brasiliensis because Lopes et al. (2007) stated that the migratory species are not reaching the reproductive process after transposing the Canoas complex.

\section{Conclusions}

In summary, the current results indicated high variability within the population groups and genetic differentiation among them. The fish stocks from these samples represent a large genetic base that will allow the fish technicians to release juveniles without genetic risks to wild populations. Genetic monitoring using the molecular markers as the RAPD or microsatellites on the wild populations, brood stocks and progenies that have participation in restocking programs is fundamental to avoid declines in the genetic variability, prevent its effects on the wild populations, and allow for insights into the preservation, management and reproduction of the $S$. brasiliensis.

\section{Acknowledgements}

The authors thank to the Duke Energy International Geração Paranapanema for providing the materials, students, teachers and technicians for their contribution, and the CAPES for granting the scholarship to the author. 


\section{References}

AGOSTINHO, A. A.; GOMES, L. C.; SUZUKI, H. I. Migratory fish of upper Paraná River basin. In: CAROLSFED, J.; HARVEY, B.; BAER, A.; ROSS, C. Migratory fishes of South America: biology, social importance and conservation status. Victoria: World Fisheries Trust, 2003. p. 19-99.

AGOSTINHO, A. A.; MARQUES, E. E.; AGOSTINHO, C. S.; ALMEIDA, D. A.; OLIVEIRA, R. J.; MELO, J. R. B. Fish ladder of Lajeado Dam: migrations on one-way routes? Neotropical Ichthyology, Porto Alegre, v. 5, n. 5, p. 121-130, 2007a.

AGOSTINHO, A. A.; THOMAZ, S. M.; GOMES, L. C. Conservation of the biodiversity of Brazil's inland waters. Conservation Biology, London, v. 19, n. 3, p. 646-652, 2005.

Agostinho, C. S.; AGOSTINHO, A. A.; PELICICE, F. M.; ALMEIDA, D. A.; MARQUES, E. E. Selectivity of fish ladders: a bottleneck in Neotropical fish movement. Neotropical Ichthyology, Porto Alegre, v. 5, n. 2, p. 205213, 2007b.

ARAKI, H.; COOPER, B.; BLOUIN, M. S. Carry-over effect of captive breeding reduces reproductive fitness of wild-born descendants in the wild. Biology Letters, London, v. 5, n. 5, p. 621-624, 2009.

ARAKI, H.; SCHMID, C. Is hatchery stocking a help or harm? Evidence, limitations and future directions in ecological and genetic surveys. Aquaculture, Amsterdam, v. 308, Supplement 1, p. S2-S11, 2010.

BENTER, T.; PAPADOPOULOS, S.; PAPE, M.; MANNS, M.; POLIWODA, H. Optimization and reproducibility of Random Amplified Polymorphic DNA in human. Analytical Biochemistry, New York, v. 230, n. 1, p. 92-100, 1995.

BONETTO, A. A.; PIGNALBERI, C.; YUAN, E. C. D. E.; OLIVEROS O. Informaciones complementarias sobre migraciones de peces en la cuenca del plata. Physis, Buenos Aires, v. 30, n. 81, p. 505-520, 1971.

BORREL, Y. J.; CARLEOS, C. E.; ASTURIANO, J. F.; BERNARDO, D.; VÁZQUEZ, E.; CORRAL, N.; SÁNCHEZ, J. A.; BLANCO, G. Use of microsatellites and a combinatorial optimization approach in the acquisition of gilthead seabream (Sparus aurata L.) broodstocks for hatcheries. Aquaculture, Amsterdam, v. 269, n. 1-4, p. 200-210, 2007.

BRITTO, S. G. C.; SIROL, R. N. Transposição de peixes como forma de manejo: as escadas do Complexo Canoas, médio rio Paranapanema, bacia do Alto Rio Paraná. In: NOGUEIRA, M. G.; HENRY, R.; JORCIN, A. (Ed.).
Ecologia de reservatórios: impactos potenciais, ações de manejo e sistemas em cascata. São Carlos: Rima, 2006. p. 285-304.

BRITTO, S. G. C.; SIROL, R. N.; VIANNA, N. C.; JARDIM, S. M.; SANTOS, J. C.; PELISARI, E. Peixes do rio Paranapanema. São Paulo: Duke Energy Internacional Geração Paranapanema, 2003. 112 p.

DIAS, J. H. P. Distribuição espacial e temporal da ictiofauna do trecho médio do rio Paranapanema e suas relações com as características morfométricas e limnológicas dos compartimentos da bacia. 2003. Tese (Doutorado em Ecologia e Recursos Naturais) Universidade Federal de São Carlos, São Carlos.

ELDRIDGE, W. H.; NAISH, K. A. Long-term effects of translocation and release numbers on fine-scale population structure among coho salmon (Oncorhynchus kisutch). Molecular Ecology, Oxford, v. 16, n. 12, p. 2407-2421, 2007.

ESGUÍCERO, A. L. H.; ARCIFA, M. S. Fragmentation of a Neotropical migratory fish population by a centuryold dam. Hydrobiologia, Den Haag, v. 638, v. 1, p. 41-53, 2010 .

EXCOFFIER, L.; LAVAL, G.; SCHNEIDER, S. Arlequin Ver. 3.1: an integrated software package for population genetics data analysis. Evolutionary Bioinformatics Online, Auckland, v. 1, n. 1, p. 47-50, 2005.

EXCOFFIER, L.; SMOUSE, P. E.; QUATTRO, J. M. Analysis of molecular variance inferred from metric distances among DNA haplotypes: application to human mitochondrial DNA restriction data. Genetics, Bethesda, v. 131, n. 2, p. 479-491, 1992.

FEITOSA, L. A.; FERNANDES, R.; COSTA, R. S.; GOMES, L. C.; AGOSTINHO, A. A. Population parameters and simulation of the yield per recruit of Salminus brasiliensis (Cuvier, 1816) from the upper Paraná River. Acta Scientiarum Biologycal Sciences, Maringá, v. 26, n. 3, p. 317-323, 2004.

FREITAS, L. A. C. M. Diversidade genética de Dourado (Salminus brasiliensis Curvier, 1816), uma espécie de grande interesse comercial no Pantanal Mato-Grossense. 2010. Tesis (Doutorado em Ecologia e Recursos Naturais) - Universidade Federal de São Carlos, São Carlos.

KITADA, S.; SHISHIDOU, H.; SUGAYA, T.; KITAKADO, T.; HAMASAKI, K.; KISHINO, H. Genetic effect of long-term stock enhancement programs. Aquaculture, Amsterdam, v. 290, n. 1-2, p. 69-79, 2009.

LEUZZI, M. S. P.; ALMEIDA, F. S.; ORSI, M. L.; SODRÉ, L. M. K. Analysis by RAPD of the genetic structure of Astyanax altiparanae (Pisces, Characiformes) 
in reservoirs on the Paranapanema River, Brazil. Genetics and Molecular Biology, São Paulo, v. 27, n. 3, p. 355362, 2004.

LOPERA-BARRERO, N. M. Conservation of Brycon orbignyanus natural populations and stocks for their reproductive, genetic, environmental sustainability: A model for species threatened with extinction. Ciencia e Investigación Agrária, Santiago, v. 36, n. 2, p. 191-208, 2009.

LOPERA-BARRERO, N. M.; POVH, J. A.; RIBEIRO, R. P.; GOMES, P. C.; JACOMETO, C. B.; LOPES, T. S. Comparison of DNA extraction protocols of fish fin and larvae samples: modified salt $(\mathrm{NaCl})$ extraction. Ciencia e Investigación Agrária, Santiago, v. 35, n. 2, p. 65-74, 2008.

LOPERA-BARRERO, N. M.; RIBEIRO, R. P.; POVH, J. A.; SIROL, R. N.; MANGOLIN, C. A. Genetic evaluation of pacu (Piaractus mesopotamicus) natural populations and from the broodstocks of a stock enhancement program using microsatellite markers. Arquivo Brasileiro de Medicina Veterinária e Zootecnia, Belo Horizonte, v. 62, n. 4, p. 954-963, 2010a.

LOPERA-BARRERO, N. M.; RIBEIRO, R. P.; POVH, J. A.; VARGAS, L.; FORNARI, D. C.; SIROL, R. N.; RODRIGUEZ-RODRIGUEZ, M. DEL P. Genetic diversity of Brycon orbignyanus in the semi-natural reproductive system, using the RAPD marker. Zootecnia Tropical, Maracay, v. 28, n. 1, p. 73-82, 2010b.

LOPES, C. M.; ALMEIDA, F. S.; ORSI, M. L.; BRITTO, S. G. C.; SIROL, R. N.; SODRÉ, L. M. K. Fish passage ladders from Canoas Complex - Paranapanema River: evaluation of genetic structure maintenance of Salminus brasiliensis (Teleostei: Characiformes). Neotropical Ichthyology, Porto Alegre, v. 5, n. 2, p. 131-138, 2007.

LOWE, A.; HARRIS, S.; ASHTON, P. Ecological genetics: design, analysis and application. Malden: Blackwell, 2004. 326 p.

LUPCHINSKI JUNIOR, E.; VARGAS, L.; POVH, J. A.; RIBEIRO, R. P.; MANGOLIN, C. A.; LOPERABARRERO, N. M. Variability evaluation of G0 and F1 generations of GIFT Nile Tilapia strain (Oreochromis niloticus) by RAPD. Acta Scientiarum Animal Sciences, Maringá, v. 30, n. 2, p. 233-240, 2008.

MACHADO, C. Aspectos reprodutivos de dourado Salminus brasiliensis (Cuvier, 1816) (Teleostei, Characidae) na região do Alto Rio Uruguai, Brasil. 2003. Dissertação (Mestrado em Aquicultura) - Universidade Federal de Santa Catarina, Florianópolis.
MILLER, M. P. Tools of population genetic analysis (TFPGA) 1.3: a windows program for the analysis of allozyme and molecular population genetic data. Utah: Utah State University, 1997. 33 p.

NEI, M. Estimation of average heterozygosity and genetic distance from a small number of individual. Genetics, Bethesda, v. 89, n. 3, p. 583-590, 1978.

PAMPONET, V. C. C.; CARNEIRO, P. L. S.; AFFONSO, P. R. A. M.; MIRANDA, V. S.; SILVIO JÚNIOR, J. C.; OLIVEIRA, C. G.; GAIOTTO, F. A. A multi-approach analysis of the genetic diversity in populations of Astyanax aff. bimaculatus Linnaeus, 1758 (Teleostei: Characidae) from Northeastern Brazil. Neotropical Ichthyology, Porto Alegre, v. 6, n. 4, p. 621-630, 2008.

PAUlA, F. M. Diversidade genética de Prochilodus lineatus (Pisces Characiformes) das escadas de transposição de peixes das usinas hidroelétricas do complexo Canoas - Rio Paranapanema. 2006. Dissertação (Mestrado em Genética e Biologia Molecular) - Universidade Estadual de Londrina, Londrina.

POVH, J. A.; RIBEIRO, R. P.; LOPERA-BARRERO, N. M.; GOMES, P. C.; BLANCK, D. V.; VARGAS, L.; JACOMETO, C. B.; LOPES, T. S. Monitoring of the genetic variability of pacu, Piaractus mesopotamicus, of the stock enhancement program of the Paranapanema River. Arquivo Brasileiro de Medicina Veterinária e Zootecnia, Belo Horizonte, v. 61, n. 5, p. 1191-1195, 2009.

POVH, J. A.; RIBEIRO, R. P.; SIROL, R. N.; STREIT JR, D. P.; MOREIRA, H. L. M.; SIEWERDT, F.; LOPERABARRERO, N. M.; MANGOLIN, C. A.; VARGAS, L. Microsatellite Analysis of the Parental Contribution of Piaractus mesopotamicus to the Production of Offspring in the Semi-natural System of Reproduction. Brazilian Archives of Biology and Technology, Curitiba, v. 53, n. 2, p. 389-396, 2010.

POVH, J. A.; RIBEIRO, R. P.; SIROL, R. N.; STREIT JÚNIOR, D. P.; LOPERA-BARRERO, N. M.; VARGAS, L.; GOMES, P. C.; LOPES, T. S. Genetic diversity of pacu from the Paranapanema River and from the broodstock of a stock enhancement program. Pesquisa Agropecuaria Brasileira, Brasília, v. 43, n. 2, p. 201-206, 2008.

RAMOS,J.V.B.EstudodaestruturagenéticadeLeporinus elongatus (Pisces, Characiformes) no complexo Canoas - Rio Paranapanema. 2007. Dissertação (Mestrado em Genética e Biologia Molecular) - Universidade Estadual de Londrina, Londrina.

RAYMOND, M.; ROUSSET, F. An exact test for population differentiation. Evolution, New York, v. 49, n. 6, p. 1280-1283, 1995. 
RODRIGUEZ-RODRIGUEZ, M. DEL P.; LOPERABARRERO, N. M.; RIBEIRO, R. P.; POVH, J. A.; VARGAS, L.; SIROL, R. N.; JACOMETO, C. B. Genetic diversity of piracanjuba used in stock enhancement programs with microsatellite markers. Pesquisa Agropecuária Brasileira, Brasília, v. 45, n. 1, p. 56-63, 2010.

SVERLIJ, S. B.; ESPINACH ROS, A. El dorado, Salminus maxillosus (Pisces, Characiformes) en el río de la Plata y río Uruguay inferior. Revista de Investigación, Desarrollo y Pesquisa, Mar del Plata, v. 6, n. 1, p. 57-75, 1986.

VIANA, A. P.; LUCENA FRÉDOU, F.; FRÉDOU, T.; TORRES, M. F.; BORDALO, A. O. Fish fauna as an indicator of environmental quality in an urbanized region of the Amazon estuary. Journal of Fish Biology, London, v. 76, n. 3, p. 467-486, 2010.
WEIR, B. S.; COCKERHAM, C. C. Estimating F-statistics for the analysis of population structure. Evolution, New York, v. 38, n. 6, p. 1358-1370, 1984.

WORKMAN, P. L.; NISWANDER, J. D. Population studies on southwestern Indian tribes. II. Local genetic differentiation in the Papago. American Journal of Human Genetics, Baltimore, v. 22, n. 1, p. 24-49, 1970.

WRIGHT, S. Evolution and genetics of populations. Chicago: University of Chicago Press, 1978. 511 p.

YEH, F. C.; BOYLE, T. Y. Z.; XIYAN, J. M. POPGENE Version 131: microsoft window-based freeware for population genetic analysis. Alberta: University of Alberta and Center for International Forestry Research, 1999. 29 p. 
